\title{
A PROPOSED TARGET STATE FOR A FLOODPLAIN FOREST ECOSYSTEM WITHIN AN ECOLOGICAL NETWORK, WITH REFERENCE TO THE ECOLOGICAL REQUIREMENTS OF AN UMBRELLA BIRD SPECIES: THE COMMON KINGFISHER
}

\begin{abstract}
IVO MACHAR
Department of Biology, Faculty of Education, Palacky University Olomouc, Purkrabská 2, 771 40, Olomouc, Czech Republic. Tel.: +420/58563 5183, E-mail: ivo.machar@upol.cz

Received: $8^{\text {th }}$ October 2008 , Accepted: $10^{\text {th }}$ December 2008

Abstract

The present day cultural landscape of Europe is comprised of an ecological network of corridors and core areas (biocentres). This article proposes the use of umbrella species to define the target state of an ecosystem in a floodplain biocentre of the European Ecological Network. The umbrella species used were chosen to represent typical bird species of forested floodplains. Case studies were developed in the Litovelské Pomoraví Protected Landscape Area, a Bird Area in the Czech Republic.
\end{abstract}

Keywords Biocentre, Important Bird Area, floodplain forest, forest management, important European bird species.

\section{INTRODUCTION}

Landscape structures affect both the persistence and movement of biota in landscape ecosystems (Naveh and Lieberman 1994). Landscape structures, however, are significantly influenced by anthropogenic impacts, the effects of which increase with the area of the Earth's surface influenced by human activities (Vitousek et al. 1997). Landscape fragmentation represents a very important anthropogenic impact on ecosystems (Schwartz 1997). Fragmentation is therefore considered to be one of the central topics of landscape ecology, closely related to the issue of nature conservation biology (Saunders et al. 1991). The key to understanding the extent to which fragmentation affects the biota within a landscape is the size of individual "islands" (fragmented habitats) and how isolated are those islands (MacArthur and Wilson 1967). This topic is complex, however, and cannot be reduced to island biogeography alone as studies of biodiversity at the landscape level must also take into account a number of other factors. These include the overall heterogeneity of the landscape (Kie et al. 2002), ecotones in the landscape (Cadenasso et al. 2003), metapopulation theory (Hanski 1999), the source-sink theory (With and King 2001) and others (for more details see $\mathrm{Gu}$ et al. 2002). The results of biodiversity conservation efforts in fragmented landscapes indicate that even small preserves can contribute to the maintenance of species diversity (Shafer 1995; Fischer and Lindenmayer 2002). A system of small and isolated preserves in a fragmented landscape, however, is unable to preserve populations of some bird species (Opdam 1991), large mammals (Noss et al. 1996) and, especially, a large number of animal species with a metapopulation life strategy (Wiens 
1997). It is also known that fragmentation of indigenous ecosystems opens up the landscape to alien species that may displace indigenous species through mutual competition (Poschold et al. 1996).

The concept of an ecological network (Bennet 1994) goes some way to addressing the issues connected with isolation of ecosystems in the landscape (also known as patches). These ecological network are better known as habitat networks in American and Australian ecological literature (Forman 1995; Hobbs 1993). A similar approach is also incorporated in the theory of landscape connectivity, in which the landscape matrix isolates individual habitat elements and represents a barrier hindering the movement of organisms (Goodwin 2003; McIntyre and Hobbs 2001; Sondgerath and Schroder 2002). Ecological networks represent a spatial concept used for the purposes of sustainable landscape development planning and as the main instrument for maintaining biodiversity at the landscape level (Opdam et al. 2005).

The ecological network concept is based on landscape corridors, functional features in the landscape that alleviate the effects of fragmentation (Hobbs and Willson 1998). Landscape corridors are always specific to the particular types of organism that use them (Brooker et al. 1999), e.g. a corridor for invertebrates will have completely different spatial parameters than functional corridors for large carnivorous mammals (Collinge 2000; Beier 1993). The significance of landscape corridors for biota, however, can be rather controversial (Harrison and Taylor 1997). The corridor theory has been undergoing continuous development, therefore, and has been the subject of much discussion (for an upto-date overview see Farina 2006).

Despite this, ecological networks have been incorporated into landscape planning and landscape management programmes in many parts of the world. In the eastern part of North America, greenways have been under development for some time (Smith and Hellmund 1993) and, though they have been constructed mainly for recreational and aesthetic purposes, they also bring considerable benefits to biodiversity in the landscape (Hay 1991). An ecological network that reconnects the remains of native ecosystems has been constructed in the Western Australian agricultural landscape known as the Wheatbelt region as part of the landscape planning process (Lambeck and Hobbs 2002).

Ecological networks play an essential role in landscape and land-use planning in Europe (Jongman 1995). When establishing land-use plans during the creation of the Natura 2000 Ecological Network, European Union member states were recommended to attempt to preserve landscape components which, with respect to their linear and uninterrupted structure or their function as "stepping stones", play a crucial role in the migration, spreading and exchange of genetic information of free-living species (Roth 2003). Ecological networks in individual European countries have usually been implemented at several geographical levels (i.e. national, regional and/or local). There has been an ongoing effort throughout Europe to connect the various existing ecological corridors into a European (or Pan-European) Ecological Network (Míchal 1999a), in which keystone areas are spatially structured using a principle similar to that of the biosphere reserve (Dasmann 1988). The Czech Territorial Systems of Ecological Stability (TSES) concept (Buček et al. 1996; Buček et al. 2007), which is also applied in a similar manner in Slovakia (Šteffek et al. 1995), represents a unique practical application of ecological networks in land-use planning and nature conservation. TSES are planned using biogeographic differentiation of the landscape into biogeocenological arrangements on a supra-regional, regional and local level, forming a network of biocentres connected with biocorridors (Buček and Lacina 2006). Conservation and the creation of TSES are considered priorities of environmental legislation in the Czech Republic (Miko et al. 2005). At present, individual biocorridors and 
biocentres are gradually being implemented in some areas of the Czech Republic, usually as part of a process of complex land modification (Maděra 2002). It has been confirmed that biocorridors on the local level of TSES should respect ecological requirements of species for the benefit of which they should fulfil their main functions (Vrabec et al. 2008).

As regards forests, requirements for the formation of a TSES are primarily the accurate territorial delimitation of the area involved and special management measures for forest biocentres (Macků 1992). Much careful attention has been paid to the spatial parameters of TSES forest biocentres (Macků and Míchal 1990), therefore, and a rare consensus has been reached concerning the spatial parameters of regional level biocentres in forest ecosystems that develop without intervention (Vacek 2003). On the other hand, little attention has so far been paid to the target state of forest ecosystems in TSES biocentres, even though this represents a basic requirement for the determination of forest management principles in biocentres and is a frequently occurring problem for conservation authorities during the approval process for forest management plans. In general, the target state of TSES forest biocentres is interpreted as their "natural potential vegetation" (Neuhäuslová et al. 1998). This concept is rather problematic, however, and especially so as regards floodplain forest ecosystems, which are among the most species rich of Central European forest types (Klimo and Hager 2001; Prach et al. 1996). These ecosystems are subject to anthropogenic influence and, in a European context, we do not know the "natural state" of these forests before they were substantially influence by mankind (Maděra et al. 2008).

This paper proposes an ecosystem target state for the biogeocenosis for a regional TSES biocentre (the Litovelské Pomoraví Protected Landscape Area (PLA)), a hardwood floodplain forest of a large river. This target state is based upon the ecological requirements of selected important European bird species that function as umbrella species (Lambeck 1997). This paper has been prepared using information published in a series of case studies concerning the Litovelské Pomoraví PLA and Important Bird Area (Czech Republic).

\section{METHODOLOGY AND REFERENCE MATERIALS}

\section{Study Area}

The floodplain forest of the Litovelské Pomoraví PLA and Important Bird Area (Figure 1) stretches across the River Morava floodplain in the eastern part of the Czech Republic (for a full description of the PLA, see Poprach et al. 2002).

The study area is situated at geographic coordinates $17^{\circ} 03^{\prime} \mathrm{E}, 49^{\circ} 42^{\prime} \mathrm{N}$ at a height of 228-237 $\mathrm{m}$ a.s.l. The potential natural vegetation of the area is represented by alluvial woodland forests of the phytocenological alliance Alnion incanae (Neuhäuslová 2000). The ecological backbone of the area is formed by the naturally meandering River Morava (Figure 2). According to the Czech typology of biotopes (Chytrý et al. 2001), the area comprises lowland river, muddy and gravel river bank, and softwood and hardwood floodplain forest biotopes. An overview of the basic biogeocenological units (Buček and Lacina 1999) within the study area is shown in Table 1. The detailed characteristics of these biotopes, as well as a detailed description of the study area, are covered in a paper by Machar (2008a). 
Fig.1: Study area and localities in the Czech Republic

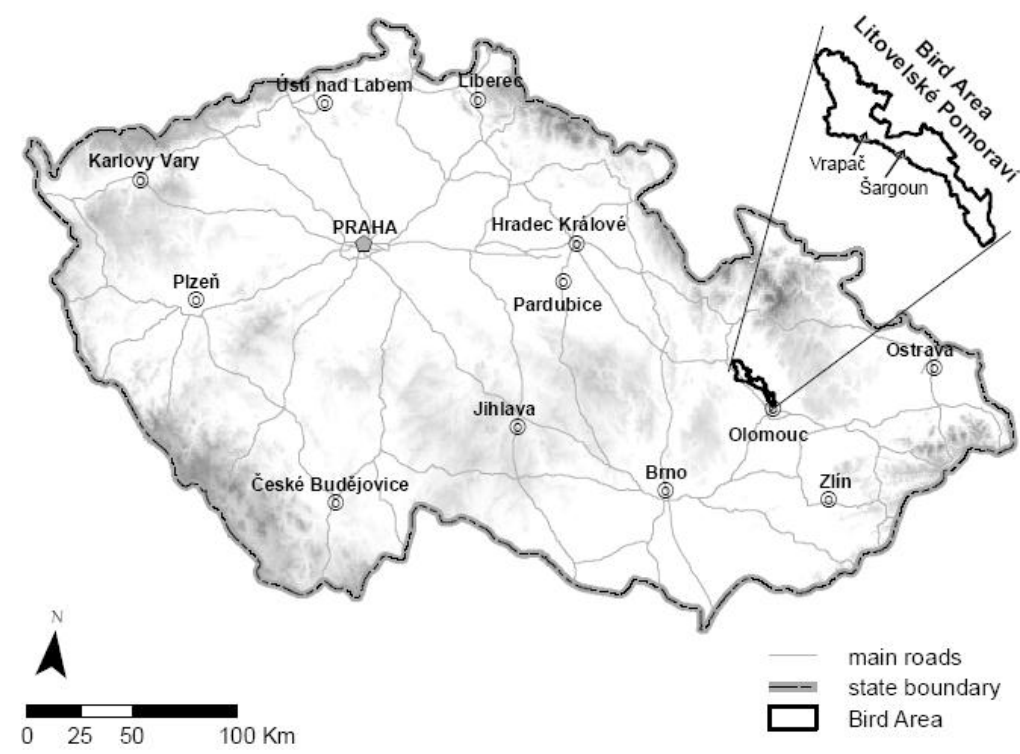

Fig.2: Meandering river Morava, Litovelské Pomoraví

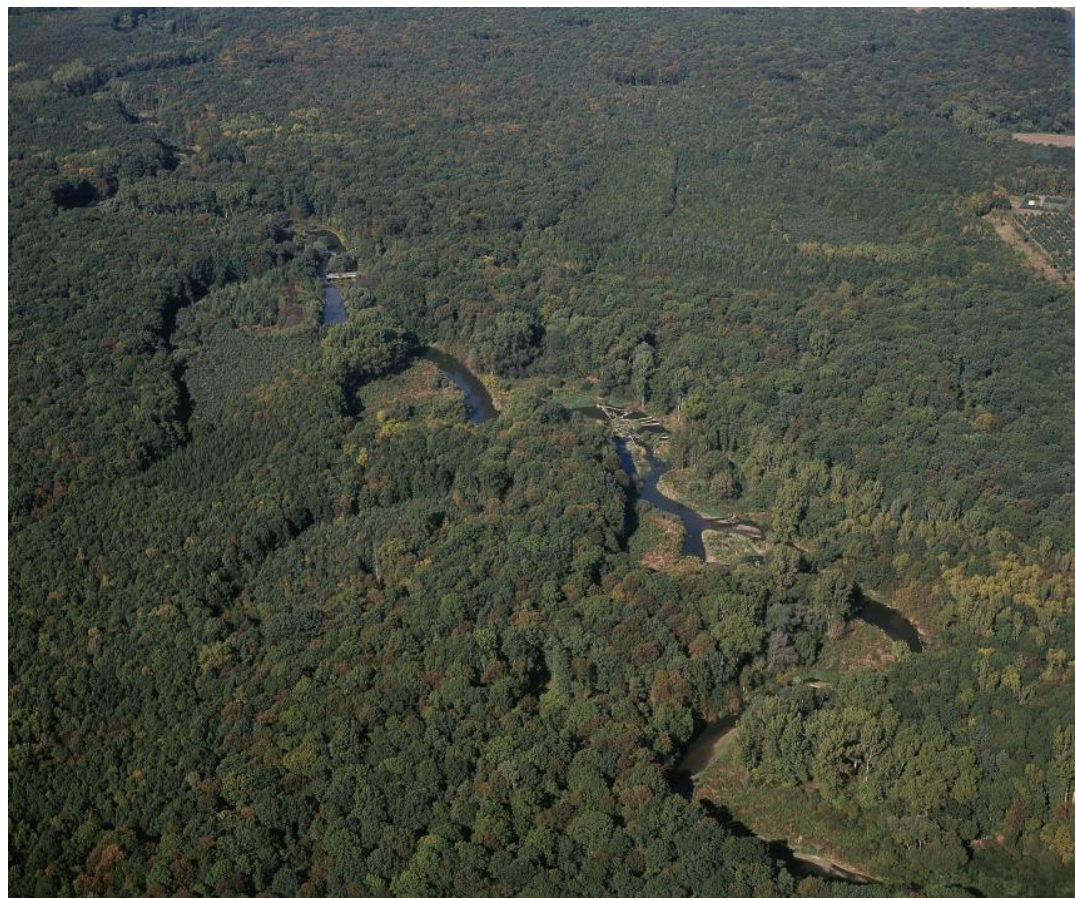


Table 1: Groups of geobiocoene types (GGT) in the PLA Litovelské Pomoraví

\begin{tabular}{|c|c|c|c|}
\hline $\begin{array}{c}\text { Abbreviation of GGT } \\
\text { (Buček, Lacina,1996) }\end{array}$ & Name of GGT & $\begin{array}{c}\text { Proportions of FST } \\
\text { in the PLA (ha) }\end{array}$ & $\begin{array}{c}\text { Proportions of FST } \\
\text { in the PLA (\%) }\end{array}$ \\
\hline A B-C 5a & Saliceta albae sup. & 86,18 & 3,6 \\
\hline 2 B-C (4) 5a & $\begin{array}{c}\text { Querci roboris- } \\
\text { fraxineta sup. }\end{array}$ & 302,83 & 12,9 \\
\hline 2 C (4) 5a & $\begin{array}{c}\text { Ulmi-fraxineta populi } \\
\text { sup. }\end{array}$ & 340,13 & 14,5 \\
\hline 2 BC-C (3)4 & $\begin{array}{c}\text { Ulmi-fraxineta carpini } \\
\text { sup. }\end{array}$ & 1512,33 & 64,6 \\
\hline S BC 5b & $\begin{array}{c}\text { Alni glutinosae- } \\
\text { saliceta sup. }\end{array}$ & 98,52 & 4,4 \\
\hline
\end{tabular}

\section{Selection of Umbrella Species}

Umbrella species have large home ranges and extensive requirements as regards biotope type. Conservation of the biotope connected with these populations, therefore, ensures biotope conservation for a wide spectrum of other biological species (Hunter and Gibbs 2007). Birds were selected as the model umbrella species for determining the target form of the Litovelské Pomoraví PLA biocentre discussed in this paper. Bird communities represent a suitable model for ecological studies of forest environments (Wiens 1989) and ecological connections between bird species structure, forest age and bird community structure are well known (see Korn̆an 2006; Petty and Avery 1990; Sallabanks et al. 2000). In addition, many bird species typically inhabiting forest environments are especially sensitive (susceptible) to the spatial area of their habitats, and this will naturally influence the determination of the spatial area of the biocentre. Such "area-sensitive" bird species are particularly found nesting in the forest interior, and are known as "interior species" (Gibbs and Faaborg 1990).

Three bird species were chosen as umbrella species for this study. These include two interior species of the hardwood floodplain forest, the middle spotted woodpecker Dendrocopos medius, a year-round resident, and the collared flycatcher Ficedula albicollis, a migrant species. In addition, a species was also chosen that is specifically bound to the river biotope, the common kingfisher Alcedo atthis. These three species also form a "defined subject" for conservation of the Litovel-Morava river basin Important Bird Area (Machar 2007a).

The middle spotted woodpecker's lifecycle is bound to oaks Quercus sp. and, therefore, it prefers to nest in floodplain forests and thermophilic coppice biotopes (Cepák et al. 2008; Št'astný et al. 2006). Bird-ringing has shown that this species is present year-round in its nesting range in the Czech Republic, although exceptional trips to locations outside its nesting range during non-nesting periods have also been recorded (Hudec et al. 2005). Pavlík (1993) has suggested that both the behaviour and method of food collection of the middle spotted woodpecker differs from that of the great spotted woodpecker Dendrocopos major, preventing mutual competition and enabling both species to use the same food niche in the same biotope. Old, unsound or dry trees are mainly used for nesting. An extensive study performed in a number of European floodplain forests has shown that this species nests exclusively in trees that have been parasitized by wood-rotting fungi (Pasinelli 2007). Hagemeijer and Blair (1997) have suggested that, in order to prosper, a population of middle spotted woodpeckers may need a large stretch of continuous forest of at least 40 (results from Switzerland) to 70 ha (results from Sweden). This species can therefore be considered as a forest-interior species inhabiting old floodplain forests and coppices 
regarded as potential natural vegetation (Neuhäuslová 2000), making it an umbrella species for populations in this type of ecosystem.

Following its return from over wintering in central and southern Africa at the end of April, the collared flycatcher nests in the PLA until its migration at the turn of August and September. This bird nests exclusively in tree hollows or in nesting boxes, the installation of which can help to increase local numbers of this species (Král 1991). A large proportion of the males is polygamous and has more than one territory (Král 1991). The collared flycatcher prefers older deciduous and mixed forests or parks, pond dams with old trees and lowlands as its nesting biotope. There has been a recent increase noted in the numbers of this species in the Czech Republic (Št'astný et al. 2004). Approximately 1,300 to 1,800 pairs of flycatchers currently nest in the Litovelské Pomoraví PLA (Poprach et al. 2002). For these reasons, the collared flycatcher is considered an equally good umbrella species as the middle spotted woodpecker.

The common kingfisher is naturally bound to water courses at lower altitudes, and especially during the nesting season. The kingfisher population in the Czech Republic is partly comprised of resident birds (dwelling near their nesting area during mild winters) and birds of passage (birds that move to unfrozen stretches when water courses become frozen, or to urban areas, many kilometres from the nesting area) and, predominantly, by migrating birds (Hudec et al. 2005). The kingfisher builds its nest in vertical erosion banks. The nesting area always includes a stretch of watercourse or the banks of a dam, and its borders are delimited by so-called "return points". The length of the nesting area can, however, vary substantially between years and localities. The length of the nesting area also depends on the number of nesting pairs, on nesting opportunities and on food availability, though it does not usually exceed $2 \mathrm{~km}$ (Čech 2006). The common kingfisher may reliably be considered as an umbrella species for a meandering river ecosystem.

\section{Methodology for Assessing the Ecological Requirements of the Selected Umbrella Species}

Data were collected from a number of previous studies. Tomialojc' (1980) used a classic combined method of mapping nesting bird areas in order to gain field data. Quantitative ornithology and field ecology methods were used for the assessment of ornithocenoses structure, comparison of ornithocenoses and calculation of community diversity indices by Janda and Řepa (1986) and Losos (1992). The two-sample t-test was used for statistical data processing (Zvára 2006) using Minitab software v. 15.1.1.

The results of a study from 2006-2007 on the structure of bird communities at Šargoun and Vrapač (see Figure 1) were used to assess the influence of long-term conservation of the forest ecosystem on the selected umbrella bird species. The biotope forms extensive complexes in developed areas of hardwood floodplain forest on river floodplains (Chytrý et al. 2001), which have been preserved for a long time in the form of natural preserves excluding forestry interventions. The PLA contains extensive complexes of hardwood floodplain forest that have been preserved for many years as nature reserves with no forestry intervention (Chytrý et al. 2001). Data on the structure and quantitative characteristics of the ornithocenoses were statistically compared with data gathered during research that took place at the same localities 20 years earlier using the same methods and which were published as a preliminary statement (Machar 2008b).

Since 1995, a study of the effects of fragmentation caused by forest harvesting interventions (clear-felling) on the selected umbrella bird species has been underway in the softwood and hardwood floodplain forest biotope types in the Litovelské Pomoraví PLA and Important Bird Area (Chytrý et al. 2001). Data obtained on the structure and 
quantitative characteristics of the ornithocenoses before (1995-1996) and after (20062007) forest fragmentation have been statistically compared and some of the results already published (Machar 2008c).

Monitoring of the kingfisher has been undertaken in the Litovelské Pomoraví PLA since 1977, the results of which were used to define the ecological demands of the kingfisher as an umbrella species (Machar 2007b).

\section{Definition of the Target State of an Ecosystem in the TSES Biocentre}

In this article, the proposed target state of an ecosystem is based on the definition of a biocentre described under Czech legislation, i.e. a biotope or group of biotopes in a landscape, the form and size of which allow for the permanent existence of the natural or changed, yet nearly-natural, ecosystem (Stejskal 2006). A regional level of TSES was selected (Míchal 1996) for this paper, as there is a definite possibility that the forest ecosystem will be left to permanent spontaneous development (succession) in a regional TSES biocentre. In the long term, this should lead to a state close to the biotope's potential natural vegetation (Jelínek 2007; Míchal 1999b).

\section{RESULTS}

\section{Long-Term Conservation of Biotopes and Umbrella Bird Species}

Results of the study on the effects of long-term conservation of floodplain forest ecosystems on bird community structure (Machar 2008b) show that, between 1986 and 2007 (during which the ecosystem was under a non-intervention regime), the overall density of ornithocenoses increased, accompanied by a slight (statistically insignificant) increase in the overall diversity of the bird community (Table 2).

Table 2: Changes of basic characteristics of breeding bird communities in the localities Vrapač and Šargoun between 1986 - 2007

\begin{tabular}{|l|l|l|l|l|}
\hline \multirow{2}{*}{ Characteristics } & \multicolumn{2}{|l|}{ Locality Vrapač } & \multicolumn{2}{l|}{ Locality Šargoun } \\
\cline { 2 - 5 } & 1990 & 2007 & 1986 & 2007 \\
\hline $\begin{array}{l}\text { Amount of breeding } \\
\text { species }\end{array}$ & 23 & 31 & 37 & 33 \\
\hline $\begin{array}{l}\text { Density of entire bird } \\
\text { communities } \\
\text { (pairs/10 ha) }\end{array}$ & 91,70 & 125,9 & 79,2 & 134,7 \\
\hline $\begin{array}{l}\text { Statistics of changes of } \\
\text { density of bird } \\
\text { communities by T-test }\end{array}$ & $\mathrm{T}=2,071 ; \mathrm{P}=2,014$ & $\mathrm{~T}=2,97 ; \mathrm{P}=2,004$ \\
\hline Species diversity index & 3,76 & 4,35 & 3,00 & 4,46 \\
\hline $\begin{array}{l}\text { Species equitability } \\
\text { index }\end{array}$ & 0,85 & 0,88 & 0,81 & 0,89 \\
\hline $\begin{array}{l}\text { Density of Ficedula } \\
\text { albicollis (pairs/10 ha) }\end{array}$ & 7,5 & 9,9 & 8,0 & 10,4 \\
\hline $\begin{array}{l}\text { Density of } \\
\text { Dendrocopos medius } \\
\text { (pairs/10 ha) }\end{array}$ & 0,5 & 0,8 & 0,9 & 1,7 \\
\hline
\end{tabular}


There has, however, been a significant increase in the number of hollow-nesting bird species and those nesting in low bushes and on the ground (Machar 2008b). The overall diversity of the nesting bird community has not changed greatly, partly due to the large area of forest under study and partly the marginal effect influencing data obtained in 1986. Populations of middle spotted woodpeckers and collared flycatchers remained relatively stable over the 20 years separating the studies, with just a slight increase in numbers (Table 2). The spatially differentiated floodplain forest biogeocenosis of the study area represents an optimum nesting environment for both middle spotted woodpeckers and collared flycatchers, especially due to the large number of old hollow trees, the number of which gradually grows with the age of the stand.

\section{Biotope Fragmentation and Umbrella Bird Species}

Machar (2008b) focused on the influence of fragmentation of a continuous complex of floodplain forests on the structure of the ornithocenosis, based on ornithological research in the floodplain forest performed before (1995-1996) and after (2006-2007) fragmentation took place. The diversity of nesting bird species increased slightly following fragmentation of the forest habitat, with bird species characteristic of open landscapes benefiting (Table 3 ). These species were not recorded as nesting in the PLA prior to fragmentation of the originally undivided forest ecosystem. In 2008, the bird species community in the forest fragments appeared to have changed once again (unpublished data). Fragmentation of the forest biogeocenosis through clear-cutting clearly initiated a series of changes in the diversity and density of the relatively stable nesting community of birds.

Forest fragmentation influenced the two forest umbrella species differently. Fragmentation resulted in a decrease in abundance and density of collared flycatchers of approximately $50 \%$, while the middle spotted woodpecker disappeared completely from the remaining fragments of original old forest (Table 3). Disturbance of the forest due to fragmentation, therefore, had a strongly negative impact on the nesting populations of both the selected umbrella species.

Table 3: Changes of basic characteristics of breeding bird communities BEFORE a AFTER fragmentation in the study area Litovelské Pomoraví

\begin{tabular}{|l|l|l|}
\hline Characteristics & $\begin{array}{l}\text { BEFORE } \\
\text { fragmentation } \\
1995-1996\end{array}$ & $\begin{array}{l}\text { AFTER fragmentation } \\
2006-2007\end{array}$ \\
\hline $\begin{array}{l}\text { Amount of breeding } \\
\text { species }\end{array}$ & 31 & 36 \\
\hline Density (pairs/10 ha) & 138,6 & 118,4 \\
\hline Species diversity index & 4,32 & 4,66 \\
\hline $\begin{array}{l}\text { Species equitability } \\
\text { index }\end{array}$ & 0,87 & 0,90 \\
\hline $\begin{array}{l}\text { Density of Ficedula } \\
\text { albicollis (pairs/10 ha) }\end{array}$ & 12,8 & 5,6 \\
\hline $\begin{array}{l}\text { Density of Dendrocopos } \\
\text { medius (pairs/10 ha) }\end{array}$ & 1,7 & 0 \\
\hline
\end{tabular}




\section{Factors Influencing Nesting of the Common Kingfisher in the Study Area}

Data indicates that the number of nesting pairs of kingfishers in the Litovelské Pomoraví PLA fluctuated considerably over the course of the monitoring period (Figure 3). It should be noted, however, that differences in the skill of observers and a number of other subjective factors (including the ability of the observer to manoeuvre a canoe on the river) may have influenced the number of birds determined as occupying nesting holes in individual years of the long-term monitoring exercise. The data collected around 1990 were clearly influenced by organic pollution, which had a strong impact on fish populations in the River Morava at that time. From 1987 to 2008, the same basic method was applied when monitoring nesting pairs; however, no difference was made between the first and second nesting of kingfishers until 2008, which may have caused a distortion in the data obtained so far.

Fig.3: State of local population of Alcedo atthis on the Morava River in the area of Litovelské Pomoraví in the period 1987-2008

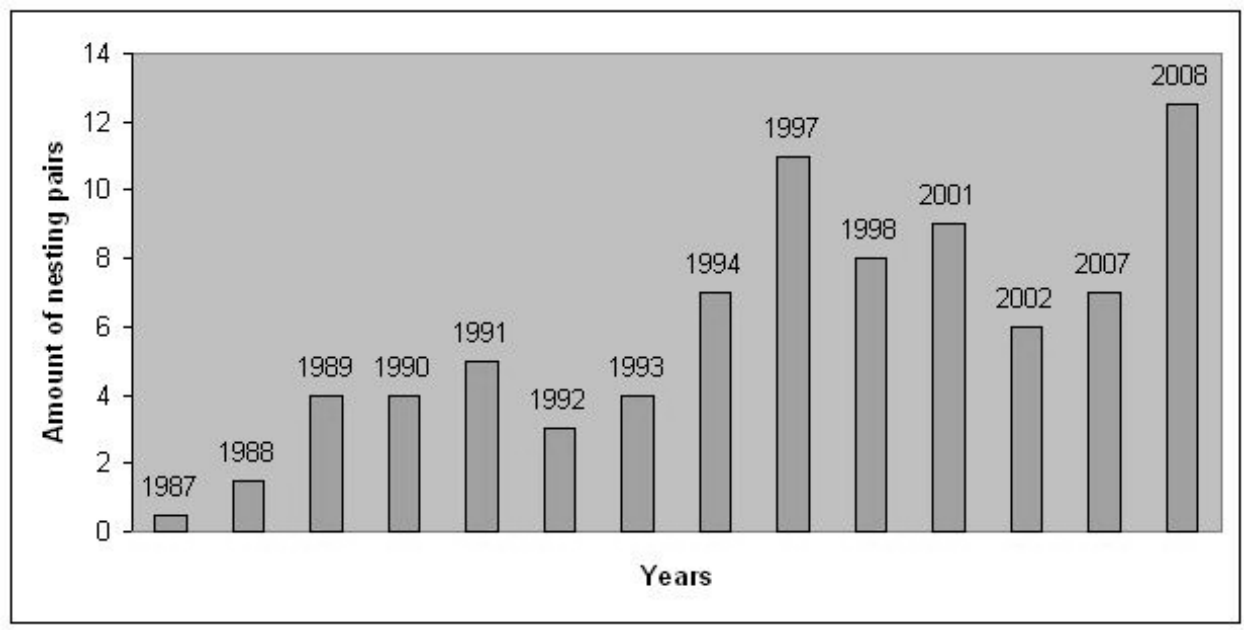

\section{Factors Influencing Local Populations of Common Kingfisher in the Litovelské Pomoraví PLA}

Table 4 provides an overview of the main limiting factors affecting nesting of the common kingfisher in the Litovelské Pomoraví PLA, based on upon the results of Machar (2007b).

In the Litovelské Pomoraví PLA, the nesting population of the common kingfisher is centred upon an area around the meandering flow of the River Morava, which is closely surrounded by a complex of floodplain forests (Figure 2). Management of the floodplain forest, therefore, significantly influences the condition of the biotope as regards kingfishers. This is especially evident from the last three factors shown in Table 4. 
Table 4: The Main Factors Affecting the Nesting Population of the Common Kingfisher in the Litovel Morava River Basin

\begin{tabular}{|l|l|}
\hline Factor & $\begin{array}{l}\text { Relative level of significance of the } \\
\text { kingfisher nesting factor in the Litovel } \\
\text { Morava River Basin }\end{array}$ \\
\hline $\begin{array}{l}\text { Food availability (species composition of } \\
\text { fish community, fish size) }\end{array}$ & Unknown \\
\hline $\begin{array}{l}\text { Weather curve in the winter preceding the } \\
\text { nesting period }\end{array}$ & $\begin{array}{l}\text { Obviously high, has not been evaluated in } \\
\text { detail }\end{array}$ \\
\hline $\begin{array}{l}\text { Weather curve in the nesting period, esp. the } \\
\text { influence of precipitation on water } \\
\text { transparency }\end{array}$ & High \\
\hline Floods in the nesting period & High \\
\hline Disturbance caused by water sportsmen & Low \\
\hline Disturbance caused by fishermen & High \\
\hline Grain size of the substrate on river banks & Unknown \\
\hline Succession of river banks & High \\
\hline Trees fallen into the river bed & High \\
\hline $\begin{array}{l}\text { Trees on river banks the branches of which } \\
\text { grow above the water level }\end{array}$ & High \\
\hline
\end{tabular}

\section{The Proposed Target State of an Ecosystem in a Biocentre}

Research data obtained thus far into the ecological requirements of the selected umbrella species indicates that the condition of their nesting biotope is greatly affected by forest management.

Populations of interior bird species in floodplain forests that are attached to forest stands, such as the middle spotted woodpecker, and species that build nests exclusively in tree hollows or nest boxes, such as the collared flycatcher, are positively affected by long-term forest conservation (e.g. prolonging the rotation period of old forest stands) and negatively affected by fragmentation of continuous forest complexes by clear-cutting. In order to preserve populations of these umbrella species, therefore, it is necessary to delimit more extensive and compact groups of older forest stands with the long-term exclusion of such forest management processes as clear-felling regeneration interventions.

Forest management methods are also decisive for the common kingfisher. The kingfisher has distinct requirements as regards the geological, geomorphological and hydrological conditions of riverbanks used for nesting. Forest management can affect all of these factors, and especially the "succession of river banks" (Table 4). The forester has a major role in determining whether large specimen trees are allowed to grow on river banks. Due to the natural lateral erosion of river banks (especially in the impact sections of meanders), these trees sometimes fall into the channel and the damage caused by their roots significantly hinders further stands. The meanders of the anastomosing river system of the Litovelské Pomoraví PLA (Kirchner and Ivan 1999) are largely stable over the long term, and they become quickly overgrown by lush vegetation that prevents kingfishers from nesting. Fallen trees along the river bank are the main cause of new vertical walls on river banks the nesting biotope of the kingfisher. Trees that fall into the river channel also represent important hunting habitats for the kingfisher (Figure 4). 
The partial results presented above allow for the proposal of a target state and system of ecosystem management for a model regional biocentre of the floodplain forest biotope within TSES (Table 5).

Table 5: Scheme of the Model Target State of a Regional Biocentre in the Floodplain Forest Ecosystem

\begin{tabular}{|l|l|l|l|}
\hline Zone & Biotope type & $\begin{array}{l}\text { Minimum spatial } \\
\text { parameters }\end{array}$ & Management \\
\hline Core zone & $\begin{array}{l}\text { Softwood and } \\
\text { hardwood } \\
\text { floodplain forest }\end{array}$ & $\begin{array}{l}\text { Minimum area of 30 } \\
\text { ha }\end{array}$ & $\begin{array}{l}\text { Without management, } \\
\text { conservation regime of } \\
\text { the so-called complete } \\
\text { biogeocenological } \\
\text { preserve }\end{array}$ \\
\hline Buffer zone & $\begin{array}{l}\text { Hardwood } \\
\text { floodplain forest }\end{array}$ & $\begin{array}{l}\text { Minimum width of } \\
\text { the zone of 50 } \\
\text { meters }\end{array}$ & $\begin{array}{l}\text { Silvicultural system of } \\
\text { standard-with-coppice }\end{array}$ \\
\hline $\begin{array}{l}\text { Difference as } \\
\text { against the model: } \\
\text { bank stands }\end{array}$ & $\begin{array}{l}\text { Meandering river } \\
\text { with bank stands }\end{array}$ & - & $\begin{array}{l}\text { Management of bank } \\
\text { stands: silvicultural } \\
\text { system of standard-with- } \\
\text { coppice }\end{array}$ \\
\hline
\end{tabular}

Fig.4: Fallen trees in the channel of the river Morava: "hunting habitats" for the Kingfisher

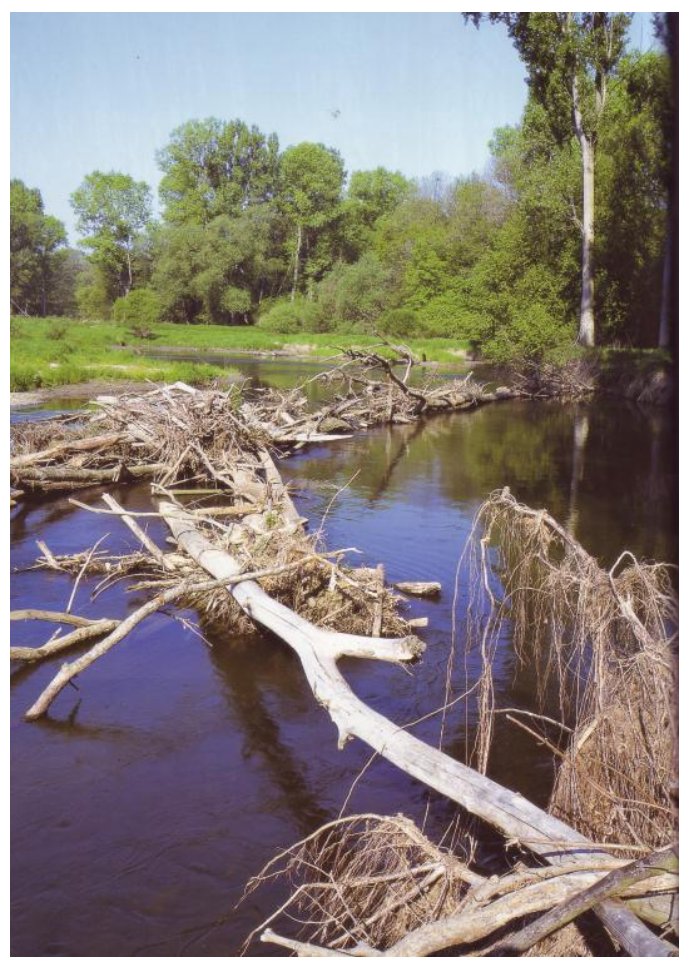


The ecological axis of the proposed biocentre is represented by the meandering River Morava, along with its associated floodplain forest (Figure 2). It has been proposed that river bank stands should be permanently cultivated as standards-with-coppice. Trees that have fallen into the river should be removed only if there is a demonstrable risk of flood damage in the developed area of some of the nearby villages. It is also necessary that the river's erosion dynamics and natural processes of accumulation are strictly protected, providing for the permanent regeneration of suitable nesting biotopes (vertical clay walls in river banks) and hunting habitats (trees in the river) for the umbrella species, the common kingfisher. The core zone of the biocentre, comprising biotopes of softwood and hardwood floodplain forest, should remain under a non-intervention regime, allowing for the spontaneous development of an ecosystem similar to those in biogeocenological preserves (Zlatník 1968). The minimum area of the non-intervention core zone should comply with the spatial parameters for a forest ecosystem capable of spontaneous development as proposed by Vacek (2003), i.e. a minimum of 30 ha in the case of floodplain forest. Such a biotope should be capable of permanently maintaining conditions suitable for the preservation of populations of the umbrella species, collared flycatchers and middle spotted woodpeckers. The non-intervention core zone of the biocentre should be separated from the surrounding commercial forest by a buffer zone to limit any conflicts of interest between nature preservation and forest management. The minimum width of this buffer zone should exceed the maximum height of the trees growing in the floodplain forest, and it should be at least $50 \mathrm{~m}$. As in the case of river bank stands, the optimum method of forest cultivation in the buffer zone is standards-with-coppice. The standards-with-coppice silvicultural system permanently preserves a specific proportion of old tree specimens that provide nesting environments for the umbrella species of collared flycatcher and middle spotted woodpecker.

\section{DISCUSSION}

Hobbs (2002) provides a summary of the present gaps in knowledge as regards ecological networks in the landscape. Among the essential landscape-ecological research needed into ecological networks, Hobbs includes research into the condition (quality) of biotopes in ecological network biocentres. This study of the Litovel-Morava river basin represents an attempt to partially fill these gaps in knowledge using the example of Central European floodplain biotopes. Softwood and hardwood floodplain forest biotopes around lowland rivers represent a vegetation type that has been significantly influenced through anthropogenic intervention (Chytrý et al. 2001; Lipský 2008; Poláček 1999). At present, we have no Central European floodplain forests in a state that would demonstrably approximate to potential natural vegetation. For example, the so-called South Moravian primary floodplain forests are formations that historically originated as grazing forests (Vrška et al. 2006). Regardless of the strong anthropogenic impact, however, floodplain forests along large rivers represent one of the richest of Central European ecosystems as regards animal species (Maděra et al. 2008). The role of mankind as a substantial factor in the origin and development of these typically man-made natural ecosystems is obvious. In this type of habitat, therefore, an "ecosystem approach", which, as a strategy of integrated ecosystem cultivation recognises mankind to be one of many ecosystems, represents the most suitable method for creating an ecological network in the landscape (Brožová 2004). The ecosystem approach fits very well into the multifunctional concept of landscape ecology (Kováŕ 2005). 
This paper proposes that the core area of such a biocentre should be left to develop through non-intervention, i.e. spontaneous succession. Despite this, it should be noted that the spontaneous development of the forest ecosystem in this area will be limited through disturbance by roe deer Capreolus capreolus (Čermák and Mrkva 2006).

The ecological significance of coppice forests (low forest and standards-with-coppice) for the preservation of biodiversity has long been known (Buckley 1992). A standards-withcoppice silvicultural system was preserved in Central European floodplain forests in a number of areas until the early 20th century (Mezera 1958). At present, however, this type of silvicultural system is extremely rare and is now even considered a natural development (Míchal et al. 1992). As a silvicultural system, standards-with-coppice reached its greatest extent around 1900 in what is now the Czech Republic, representing almost 3\%, or approximately 60,000 ha, of the total forest stand. These stands were mainly to be found in Moravia. By 1990, there was no evidence of standards-with-coppice over the whole of the Czech Republic (Kadavý et al. 2007). Paradoxically, this situation contradicts the increasing interest of conservationists in what remains of the standards-with-coppice stands as, according to Míchal (1998), these habitats are now considered the most natural preserved lowland forests and are recommended as the target form of biocentres and biocorridors in floodplain forests.

Conservation authorities in the Czech Republic have tended to display a conservative attitude towards the practical maintenance of bank stands and forest management of floodplain forests in close proximity to rivers, which has caused considerable conflict between forestry and water management interests. The proposed standards-with-coppice model of bank stand management represents a compromise between these conflicting interests. The model allows for the regular and intensive maintenance of bank stands (forest and water management requirements) as well as for the permanent presence of large trees in bank stands that do not limit fluvial geomorphological processes (nature conservation requirements). It should also be noted that the presence of the European Beaver Castor fiber in the study area is already pushing the development of bank stands toward the standards-with-coppice silvicultural system.

It is well known that forest fragmentation leads to a decrease in the population density of interior bird species, and perhaps even their disappearance (Gibbs and Faaborg 1990). This was confirmed by the results of this study of the Litovelské Pomoraví PLA. Indeed, changes in species and numbers in the forest bird community related to forest management practices are considered a definite model of anthropogenically controlled community development (Lešo 2003). The ornithological research data used in this study are comparable with data on bird communities in the floodplain forests of the Morava river basin published by Bureš and Maton (1985) and Chytil (1984).

The bird species included in this study are also subject to conservation measures due to the status of the PLA as part of the network of Important Bird Areas under Natura 2000. Much attention has been given to these species through environmental education programmes promoting the Natura 2000 network. In this way, these species have become the centre of attention of both conservationists and the public in the Litovelské Pomoraví PLA and can thus be considered as conservationist "flagship species" (Caro and Doherty 1999). This also demonstrates the mutual interconnectedness of the Natura 2000 network and the Territorial System of Ecological Stability of the landscape in the Czech Republic (Machar 2006).

The umbrella species concept is considered a useful conservation tool when determining the priorities and principles for the formation of a reserve (Roberge and Angelstam 2004). The results of this paper indicate new possibilities for use of the umbrella species concept 
when establishing elements of an ecological network in the landscape. This could be further developed, and especially in relation to new data concerning the function of corridors in the landscape, as it is known that different target species require different types of corridor (examples include Orthoptera - Jordan et al. 2003; metapopulations of butterflies Konvička et al. 2006 and Vrabec et al. 2008; and small mammals - Mabry and Barret 2002). Unfortunately, practical results of studies on metapopulations and the effects of landscape fragmentation on biota have so far been largely lacking (for birds, however, see Hinsley et al. 2006).

For practical reasons, it is clear that it will never be possible to establish landscape biocorridors and biocentres for all types of free-living organisms. The umbrella species concept, however, represents one of a number of appropriate solutions in the search for spatial parameters of components in ecological networks, such as biocorridors and biocentres.

\section{REFERENCES}

Beier, P. (1993). Determining minimum habitat areas and habitat corridors for cougars. Conservation Biology, 7: 94-108.

Bennet, G. (1994). Conserving Europe's natural heritage. Towards to European Ecological Network. London, Dordrecht, Boston, pp 334.

Brooker, L., Brooker, M. \& Cale, P. (1999). Animal dispersal in fragmented habitat: measuring habitat connectivity, corridor use and dispersal mortality. Conservation Ecology, 3: 4,

Brožová, J. (2004). Biologická rozmanitost v České republice. Současný stav a trendy. Praha, Ministerstvo životního prostředí, Praha, pp 58.

Buckeley, G.P. (1992). Ecology and Management Coppice Woodlands. Chapman \& Hall, London, pp 336.

Buček, A., Lacina, J. \& Míchal, I. (1996). An ecological network in the Czech Republic. Veronika, Brno, pp 44.

Buček, A., Lacina, J. (1999). Geobiocenologie. Mendelova zemědělská a lesnická univerzita, Brno, pp 249.

Buček, A., Lacina, J. (2006). Biogeografická diferenciace v geobiocenologickém pojetí a její využití v krajinném plánování. In: Dreslerová, J., Packová, P. (Eds.): Ekologie krajiny a krajinné plánování. pp 18-29. Sborník ekologie krajiny 2, Lesnická práce, Kostelec nad Černými lesy.

Buček, A., Maděra, P. \& Úradníček, L. (2007). Ecological network creation in the Czech Republic. Ekologie krajiny (Journal of Landscape Ecology), Vol. 0 (0): 25-31.

Bureš, S. (1988). The impact of the structure of forest on the bird communities. Acta Universitatis Agriculturae Brno, Facultas Silviculturae, 57: 247-260.

Bureš, S., Maton, K. (1985). Ptačí společenstvo typu geobiocénu Ulmi-Fraxineta populi v navrhované chráněné krajinné oblasti Pomoraví. Sylvia, 13/14: 37-46.

Cadenasso, M.L.., Pickett, S.T.A., Weathers, K.C. \& Jones, C.G. (2003). A framework for a theory of ecological boundaries. BioScience, 53 (8): 750-758.

Caro, T.M., O'Doherty, G. (1999). On the use of surrogate species in conservation biology. Conservation Biology, 13: 805-814.

Cepák, J., Klvaňa, P., Škopek, J., Schröpfer, L., Jelínek, M., Horák, D., Formánek, J. \& Zárybnický, J. (2008). Atlas migrace ptáků České a Slovenské republiky. Aventinum, Praha. 
Čermák, P., Mrkva, R. (2006). Effects of game on the condition and development of natural regeneration in the Vrapač National Nature Reserve (Litovelské Pomoraví). Journal of Forest Science, 52, 7: 329-336.

Collinge, S.K. (2000). Effects of grassland fragmentation on insect species loss, colonization, and movements patterns. Ecology, 81: 2211-2226.

Čech, P. (2006). Breeding biology of the Kingfisher (Alcedo atthis) and the possibilities of its protection in the Czech Republic. Sylvia, 42: 49-65.

Dasmann, R.F. (1988). Biosphere reserves, buffers and boundaries. BioScience, 38: 487-489.

Farina, A. (2006). Principles and Method in Landscape Ecology. Springer, Dordrecht, pp 412.

Fischer, J., Lindenmayer, D.B. (2002). Small patches can be valuable for biodiversity conservation: two case studies on birds in south-eastern Australia. Biological Conservation, 106: 129-136.

Forman, R.T.T. (1995). Land Mosaics: The Ecology of Landscapes and Regions. Cambridge University Press, Cambridge.

Gibbs, J.P., Faaborg, J. (1990). Estimating the viability of Ovenbird and Kentucky Warbler populations in forest fragments. Conservation Biology, 4: 193-196.

Goodwin, B.J. (2003). Is landscape a dependent or independent variable? Landscape Ecology, 18: 687-699.

Gu, W., Heikkila, R. \& Hanski, I. (2002). Estimating the consequences of habitat fragmentation on extinction risk in dynamic landscapes. Landscape Ecology, 17: 699-710.

Hagemeijer, W.J.M., Blair, M.J. (1997). The EBCC Atlas of European breeding birds: Their distribution and abundance. T \& D Poyser, London.

Hanski, I. (1999). Metapopulation Ecology. Oxford University Press, Oxford.

Harris, L.D. (1984). The Fragmented Forests: Island Biogeographic Theory and the Preservation of Biotic Diversity. University of Chicago Press, Chicago.

Harrison, S., Taylor, A.D. (1997). Empirical evidence for metapopulation dynamics. In Hanski, I.A., Gilpin, M.E. (Eds.): Metapopulation biology: Ecology, genetics and evolution. pp 64-92. Academic Press,

Hay, K.G. (1991). Greenways and biodiversity. In: Hudson, W.E. (Ed.): Landscape Linkages and Biodiversity. pp 162-175. Island Press, Washington DC,

Hinsley, S.A., Doherty, P.F.Jr., Bellamy, P.E. \& Grubb, T.C. Jr. (2006). Consequences of habitat fragmentation on birds: comparison between Europe and North America. Acta Zoologica Sinica, 52: 187-190.

Hobbs, R.J. (1993). Effects of landscape fragmentation on ecosystem processes in the western Australian wheatbelt. Biology Conservation, 64: 193-201.

Hobbs, R.J., Willson, A.M. (1998). Corridors: theory, practice and the achievment of conservation objectives. In: Dover J.W., Bunce, R.G.W. (Eds.): Key Concepts in Landscape Ecology. pp 265-279. International Association for Landscape Ecology, Preston.

Hobbs, R.J. (2002). Habitat Networks and Biological Conservation. In: Gutzwiller, K.J. (Ed.): Applying Landscape Ecology in Biological conservation. pp 150-170. Springer, New York, Hudec, K., Št’astný K. (2005). Ptáci - Aves. Díl II/2. Fauna ČR. Academia, Praha.

Hunter, M.L., Gibbs, J. (2007). Fundamentals of Conservation Biology. Third Edition. Blackwell Publishing, Malden, Oxford, Victoria, pp 497.

Chytil, J. (1984). Srovnání produkce ptáků a savců v lužním lese. Zprávy MOS Přerov, 42: 8188. 
Chytrý, M., Kučera, T. \& Kočí, M. (Eds.) (2001). Katalog biotopů České republiky. AOPK ČR, Praha, pp 304.

Janda, J., Řepa, P. (1986). Metody kvantitativních výzkumů v ornitologii. Moravský ornitologický spolek, Přerov.

Jelínek, P. (2007). Management lesních biocenter. In: Petrová, A., Grohmanová, L. (Eds.): ÚSES - zelená páter krajiny. pp 45-49. Sborník př́íspěvků z 6. ročníku konference CZ-IALE 4.5.9.2007 v Brně, AOPK ČR a CZ-IALE, Brno,

Jongman, R.H.G. (1995). Nature conservation planning in Europe: developing ecological networks. Landscape and Urban Planning, 32: 169-183.

Jordan, F., Baldi, A., Orci, K.M., Racz, I. \& Varga, Z. (2003). Characterizing the importance of habitat patches and corridors in maintaining the landscape connectivity of a Pholidoptera transsylvanica (Orthoptera) metapopulation. Landscape Ecology, 18: 83-92.

Jordan, F., Scheuring, I. (2004). Network ecology: topological constraints on ecosystem dynamics. Physics of Life Reviews, 1: 139-172.

Kadavý, J., Kneifl, M., Servus, M. \& Knott, R. (2007). Středni les jako prrírodě blízḱ způsob hospodaření. Význam prŕrodě blízkých způsobů pěstování lesů pro jejich stabilitu, produkční a mimoprodukční funkce. Sborník př́spěvků z vědecké konference, Kostelec nad Černými Lesy, ČZU, Praha, pp 35-43.

Kie, J.G., Bowyer, R.T., Nicholson, M.C., Boroski, B.B. \& Loft, E.R. (2002). Landscape heterogenity at different scales: effects on spatial distribution of mule deer. Ecology, 83: 530544.

Kirchner, K., Ivan, A. (1999). Anastomosing river system in PLA Litovelské Pomoraví. Geologické výzkumy na Moravě a ve Slezsku, VI: 19-20.

Klimo, E., Hager, H., (2001). The floodplain forests in Europe : current situation and perspectives. European Forest Institute research report, 10. Koninklijke Brill NV, Leiden, pp 267.

Konvička, M., Čížek, L. \& Beneš, J. (2006). Ohrožený hmyz nižinných lesů: ochrana a management. Sagittaria, Olomouc.

Korňan, M. (2006). Hodnotenie vplyvu lesohospodárskeho využívania lesov na vtáčie zoskupenia: literárna rešerš. Tichodroma, 18: 111-128.

Kováŕ, P. (2005). Ekosystémový pohled, krajinný ráz a vize multifunkčnosti. In: Maděra, P., Friedl, M. \& Dreslerová, J. (Eds.): Krajinný ráz - jeho vnímání a hodnocení v evropském kontextu. pp 77-82. Sborník ekologie krajiny 1, prŕíspěvky z konference CZ-IALE 4.-5.2.2005 v Brně, Lesnická práce, Kostelec nad Černými Lesy,

Král, M. (1991). Polyteritoriální chování a sukcesivní polygamie samců lejska bělokrkého v Nízkém Jeseníku. Panurus, 3: 159-168.

Lambeck, R.J. (1997). Focal species: a multi-species umbrella for nature conservation. Conservation Biology, 11: 849-856.

Lambeck, R.J., Hobbs, R.J. (2002). Landscape and Regional Planning Conservation: Issues and Practicalities. In: Gutzwiller, K.J. (Ed.): Applying Landscape Ecology in Biological Conservation. 360-380 pp. Springer-Verlag, New York,

Lešo, P. (2003). Breeding bird communities of two succession stages of young oak forests. Sylvia, 39: 67-78.

Lipský, Z. (2008). Changes in the land-use of the floodplains. In: Pithart, D. (Ed.): Proceedings of conference Ecosystem services of floodplain. pp 132-141. Ústav systematické biologie a ekologie, Třeboň, 
Losos, B. (1992). Ekologie živočichů. Masarykova Univerzita, Brno.

Mabry, K.E., Barret, G.W. (2002). Effects of corridors on home range sizes and interpatch movements of tree small mammal species. Landscape Ecology, 17: 629-636.

Macků, J. (1992). Územní systémy ekologické stability v lesích. In: Míchal, I., Buček, A., Hudec, K., Lacina, J., Macků, J. \& Šindelář, J. (Eds.), Obnova ekologické stability lesů. pp 130138. Academia, Praha,

Macků, J., Míchal, I. (1990). Minimální velikost lesních biocenter. Lesnictví, 36: 707-717.

MacArthur, R.H., Wilson, E.O. (1967). The theory of island biogeography. Princeton University Press, Princeton.

Maděra, P. (2002). Ekologické sitě. Sborník př́ispěvků z mezinárodní konference 23.-24.11.2001 v Brně. Geobiocenologické spisy 6, MZLU Brno, pp 273.

Maděra, P., Vukelić, J., Buček, A. \& Baričevič, D. (2008). Floodplain forest plant communities. In: Klimo, E., Hager, H., Matić, S., Anić, I. \& Kulhavý, J. (Eds.): Floodplain forests of the temperate zone of Europe. pp 102-159. Lesnická práce, Kostelec nad Černými lesy,

Machar, I. (2006). Územní systémy ekologické stability a hodnocení vlivů koncepcí a záměrů na soustavu Natura 2000. In: Petrová A., (Ed.): ÚSES - zelená páteř krajiny. pp 63-67. Sborník z konference 5.-6.9.2006, AOPK ČR, MZLU Brno, Česká společnost pro ekologii krajiny, Nadační fond prof.A.Bayera, Brno,

Machar, I. (2007a). Biodiversity of the birds in floodplain forest. In: Měkotová J. (Ed.), Říčni krajina 2007. pp 59-63. Sborník z konference, CZ-IALE a Univerzita Palackého, Olomouc,

Machar, I. (2007b). Ecology and distribution of the Kingfisher in the Bird Area Litovelské Pomoraví. In: Kopecký, M., Skarupská, H. (Eds.): I. Olomoucké dny antropologie a biologie. pp 362-368. Recenzovaný sborník z mezinárodní vědecké konference. Univerzita Palackého, Olomouc,

Machar, I. (2008a). Floodplain forests of Litovelské Pomoraví and their management. Journal of Forest Science, 54: 355-369.

Machar, I. (2008b). The impact of floodplain forest conservation to bird breeding communities. In: Bryja, J. (Ed.): Zoologické dny 2008. pp 121-122. Jihočeská univerzita, České Budějovice,

Machar I. (2008c). Vliv fragmentace na ptačí společenstvo lužního lesa. In: Bryja J. (Ed.): Zoologické dny 2008. pp 120-121. Jihočeská univerzita, České Budějovice,

McIntyre, S., Hobbs, R.J. (2001). Human impact on landscapes: matrix condition and management priorities. In: Craig J., Saunders, D.A., Mitchell, N. (Eds.): Nature Conservation 5: Nature Conservation in Production Environments. pp 301-307. Surrey Beatty and Sons, Chipping Norton, Australia,.

Mezera, A., 1958: Středoevropské nižinné luhy II. SZN, Praha, pp 362.

Míchal, I., 1996: Šest strategii pěstebniho plánováni jako rámce péče o lesní části ÚSES. Ochrana př́rody, 51 (6): 171-173.

Míchal, I., 1998: Poznámky k managementu středních lesů. In: Míchal, I., Petříček, V. (eds.): Péče o chráněná územi II. Agentura ochrany př́rody a krajiny ČR, Praha, pp 299-302.

Míchal, I., 1999a: Pan-European ecological network before and after the Pan-European conference of environmental ministers. In: Kovár, P. (ed.): Nature and Culture in Landscape Ecology (Experiences for the 3rd millenium). Proceedings of the CZ-IALE conference Present and Historical nature-Culture Interactions in Landscapes, 7.-13.9.1998, Charles University, Prague, pp 130-132.

Míchal., I., 1999b: Principy hospodaření v biocentrech územního systému ekologické stability na lesni puidě. In: Moucha, P. (ed.): Přrirodě blizké hospodaření v lesích chráněných krajinných 
oblastí. Sborník přednášek ze semináře 30.3.1999 v Průhonicích, Správa CHKO ČR, Praha, pp 47-54.

Míchal., I., Buček, A., Lacina,J., Hudec, K., Macků, J. \& Šindelář, J. (1992). Obnova ekologické stability lesů. Academia, Praha, pp 170.

Miko, L., Borovičková, H., Havelková, S., Roth, P., Stloukal, P. \& Vopálková, A. (2005). Zákon o ochraně prírody a krajiny: komentár. C.H.Beck, Praha.

Naveh, Z., Lieberman, A.S. (1994). Landscape Ecology. Theory and application (2nd ed.). Springer-Verlag, Berlin.

Neuhäuslová, Z. (1998). Mapa potenciálni přirozené vegetace ČR. Academia, Praha, pp 341.

Neuhäuslová, Z. (2000). Alnion incanae. In: Moravec, J., Husová, M., Chytrý, M. \& Neuhäslová, Z. (Eds.), Vegetation Survey of the Czech Republic, vol.2. Hygrophilous, mesophilous and xerophilous deciduous forests. pp 15-69. Academia, Praha.

Noss, R.F., Quigley, H.B., Hornocker, M.G., Merrill, T., Paquet, P.C., 1996: Conservation biology and carnivores conservation in the Rocky mountains. Conservation Biology, 10: 949963.

Opdam, P. (1991). Metapopulation theory and habitat fragmentation: a review of holarctic breeding bird studies. Landscape Ecology, 5: 93-106.

Opdam, P., Steingröver, E. \& van Rooij, S. (2005). Ecological networks: A spatial concept for multi-actor planning of sustainable landscapes. Landscape and Urban Planning, 75: 322-332.

Pasinelli, G. (2007). Nest site selection in Middle and Great Spotted Woodpeckers Dendrocopos medius and D. major: implications for forest management and conservation. Biodiversity Conservation, 16: 1283-1298.

Pavlík, Š. (1993). The population density of Dendrocopos major and Dendrocopos medius in oak tree forests in the breeding time as a result their mutual food competition. Trichodroma (Bratislava), 5: 39-44.

Petty, S.J., Avery, M.I. (1990). Forest bird communities. A review of the ecology and management of forest bird communities in relation to silvicultural practices in the British uplands. Forestry Comission Paper 26, Edinburgh, pp 41.

Poláček, L. (1999). Prehistory and history of floodplain. In: Šeffer J., Stanová V. (Eds.): Morava River Floodplain Meadows. Importance, Restoration and Management. pp 25-36. Daphne, Bratislava,

Poprach, K., Bureš, S., Dočkal, O., Kovařík, P. \& Polášek, V. (2002). Litovelské Pomoraví. In: Hora, J., Marhoul, P., Urban, T. (Eds.): Natura 2000 v České republice. pp 1-4. Česká společnost ornitologická, Praha,

Poschold, P., Bakker, J., Bonn, S. \& Fischer, S. (1996). Dispersal of plant species in fragmented landscapes. In: Settele, J., Margules, C.R., Poschold, P., Helne, K. (Eds.): Species survival in fragmented landscapes. pp 123-127. Kluwer Academic Publishers, Dordrecht,

Prach, K., Husák, Š., Černý, R., Kučera, S., Guth, J, Rydlo, J. \& Klimešová, J. (1996). Species and vegetation diversity along the river. In: Prach, K., Jeník, J., Large, A. (Eds.): Floodplain ecology and management. pp 62-80. SPB Academic Publishing, Amsterdam,

Roberge, J.M., Angelstam, P. (2004). Usefulness of the umbrella species concept as a conservation tool. Conservation Biology, 18: 76-85.

Roth, P. (2003). Legislativa Evropských společenství v oblasti územni a druhové ochrany prírody. Ministertsvo životního prostředí, Praha, pp 181.

Ružičková, J., Šíbl, J. (2000). Ecological network in landscape. Univerzita Komenského Bratislava a Slovenská polnohospodárska univerzita, Nitra, pp 182. 
Sallabanks, R., Arnett, E.B. \& Marzluff J.M. (2000). An evaluation of research on the effects of timber harvest on bird populations. Wildlife Society Bulletin, 28 (4): 1144-1155.

Saunders, D.A., Hobbs, R.J. \& Margules, C.R. (1991). Biological consequences of ecosystem fragmentation: a review. Conservation Biology, 5: 18-32.

Shafer, C.L. (1995). Values and shortcomings of small reserves. Bioscience, 45: 80-88.

Schwartz, M.W. (1997). Conservation in Highly Fragmented Landscapes. Chapman and Hall, New York.

Sondgerath, D., Schroder, B. (2002). Population dynamics and habitat connectivity affecting the spatial spread of populations - a simulation study. Landscape Ecology, 17: 1-14.

Smith, D.S., Hellmund, P.C. (1993). Ecology of Greenways. Design and Function of Linear Conservation Areas. University of Minnesota Press, Minneapolis.

Stejskal, V. (2006). Úvod do právní úpravy ochrany př́rody a péče o biologickou rozmanitost. Linde, Praha.

Šteffek, J., Háberová, I., Jančura, P., Jančurová, K., Janík, M., Koreň, M., Kramárik, J., Krištín, A., Maglocký, Š., Majzlan, O., Ot’ahelová, H., Sabo, P., straka, P., Šoltés, R. \& Uhrín, M. (1995). Significance of the national ecological network of Slovakia for the European Ecological Network. Ekológia (Bratislava), 14 (supl.1): 205- 212.

Št’astný, K., Bejček, V. \& Hudec, K. (2006). Atlas hnizdniho rozšǐrení ptáků v České republice 2001-2003. Aventinum, Praha.

Tomialojc', L. (1980). The combined version of the mapping method. In: Oelke, H. (Ed.): Proceedings of VI. International Conference Bird Census Work, pp 92-104. Gottingen.

Vacek, S. (2003). Minimum area of forest left to spontaneous development in protected areas. Journal of Forest Science, 49, (8): 349-358.

Vitousek, P.M., Mooney, H.A., Lubchenco, J. \& Melillo, J. (1997). Human domination of Earth's ecosystems. Science, 277: 494-499.

Vrabec, V., Bouberlová, J., Hanousková H., Hatlapatková, J., Marušáková, K., Pravdová, J., Prokopová, E., Spalová, M., Veselá, H. \& Cibulka, J. (2008). Problematika managementu populace ohrožených motýlů ve vztahu k ÚSES - př́klad z praxe na modráscích Maculinea. In: Petrová, A. (Ed.): ÚSES - zelená páteř krajiny. pp 88-96. Sborník př́íspěvků z konference 2.3.9.2008 v Brně, MZLU Brno a CZ-IALE, Brno.

Vrška, T., Adam, D., Hort, L., Odehnalová, P., Horal, D. \& Král, K. (2006). Developmental dynamics of virgin forest reserves in the Czech republic. Vol. II. Floodplain forests, CahnovSoutok, Ranšpurk, Jiřina. Academia, Praha.

Wiens, J.A. (1997). Metapopulation dynamics and landscape ecology. In: Hanski, I.A., Gilpin, M.E. (Eds.): Metapopulation Biology: Ecology, Genetics and Evolution. pp 43-62. Academic Press, New York,

Wiens, J.A. (1989). The ecology of bird communities. Volume 2. Processes and variations. Cambridge University Press, Cambridge, pp 316.

With, K.A., King, A.W. (2001). Analysis of landscape sources and sinks: the effects of spatial pattern on avian demography. Biological Conservation, 100: 75-88.

Zlatník, A. (1968). Teoretické zásady pro výběr a rozlohu lokalit v chráněných územích, Československá ochrana prrirody, 6: 31-46.

Zvára, K. (2006). Biostatistika. Karolinum, Praha. 